\author{
Janusz Kot ${ }^{*}$ Ewa Kraska**
}

\title{
WSPÓLPRACA PRZEDSIĘBIORSTW \\ ZLOKALIZOWANYCH W KLASTRACH Z OTOCZENIEM NAUKOWYM W PROCESACH ROZWOJU REGIONALNEGO (NA PRZYKŁADZIE WOJEWÓDZTWA ŚWIĘTOKRZYSKIEGO)
}

\begin{abstract}
Streszczenie. Artykuł zawiera analizę relacji między przedsiębiorstwami zlokalizowanymi w klastrach województwa świętokrzyskiego a otoczeniem naukowym. Relacje te są przedmiotem badania zarówno w odniesieniu do zasięgu przestrzennego (regionalnego i ponadregionalnego), jak i form współpracy. Prezentowane w artykule wyniki badań są podstawą do formułowania wniosków w odniesieniu do znaczenia współpracy między obiema sferami (gospodarczej i naukowej) dla rozwoju klastrów, przedsiębiorstw w nich zlokalizowanych, jak i rozwoju regionalnego.

Słowa kluczowe: klastry, otoczenie naukowe, rozwój regionalny.
\end{abstract}

\section{WSTĘP}

Rozwój regionalny jest przedmiotem badań, które w efekcie mają prowadzić do wskazania rekomendacji odnoszących się do kształtowania procesów znajdujących swoje odzwierciedlenie nie tylko w konkurencyjności i innowacyjności regionalnej, ale także przyczyniających się do rozwoju gospodarki w skali makro. Terminu rozwój regionalny używa się dla przedstawienia rozwoju szerszego układu, jakim jest kraj w podziale na jednostki - regiony (Stawasz 2000: 19). Analizowanie procesów rozwoju regionalnego powinno uwzględniać obserwacje i zrozumienie procesów zachodzących w ramach gospodarek narodowych i gospodarki globalnej. Do tego dodać należy zmiany i tendencje w kształtowaniu nowych przestrzennych organizacji form produkcji. Wpływają na nie zmiany w wartościowaniu czynników lokalizacji działalności gospodarczej i korespondujących z nimi czynników rozwoju regionalnego. Coraz bardziej popularną (ze względu na swoją efektywność) formą przestrzennej organizacji produkcji są

\footnotetext{
* Politechnika Świętokrzyska, Wydział Zarządzania i Modelowania Komputerowego, Katedra Zarządzania i Marketingu, kot402@op.pl

${ }^{* *}$ Uniwersytet Jana Kochanowskiego w Kielcach, Instytut Prawa, Ekonomii i Administracji, Doktorant w Katedrze Gospodarki Regionalnej i Środowiska, Instytut Gospodarki Przestrzennej, Wydział Ekonomiczno-Socjologiczny Uniwersytetu Łódzkiego, ekraska@ujk.edu.pl
} 
klastry. Są one egzemplifikacją rozwoju opartego na tworzeniu i współpracy w ramach powiązań sieciowych. Jedną z najważniejszych form współpracy jest współdziałanie sfery gospodarczej, tj. przedsiębiorstw z jednostkami naukowymi. Celem artykułu jest wykazanie, na ile przedsiębiorstwa zlokalizowane w klastrach województwa świętokrzyskiego współpracują z otoczeniem naukowym o zasięgu regionalnym, jak i ponadregionalnym. Przedmiotem badania są przedsiębiorstwa zlokalizowane $\mathrm{w}$ klastrach województwa świętokrzyskiego w aspekcie zasięgu przestrzennego, jak i form współpracy ze sferą nauki. Autorzy artykułu stawiają następującą hipotezę badawczą: przedsiębiorstwa działające $\mathrm{w}$ klastrach częściej podejmują współpracę $\mathrm{z}$ jednostkami otoczenia naukowego zlokalizowanymi w regionie świętokrzyskim niż poza nim.

\section{REGION I CZYNNIKI ROZWOJU REGIONALNEGO W ASPEKCIE POWIĄZAŃ SIECIOWYCH}

Rozważania nad regionem, jego rolą i procesami w nim zachodzącymi należą do zagadnień wielowątkowych. W literaturze przedmiotu występuje wiele określeń regionu, stąd złożoność tego pojęcia. Ze względu na zakres artykułu będziemy posługiwać się pojęciem regionu w ujęciu ekonomicznym, gdzie region to terytorialna substruktura gospodarki narodowej określonego państwa, kompleks produkcyjno-usługowy wyróżniający się od otaczających obszarów formami zagospodarowania (Fajferek 1966: 9), które wynikają ze społecznego i terytorialnego podziału pracy. Inaczej jest to obszar o określonej specjalizacji gospodarczej, ukształtowany poprzez wykorzystanie dostępnych zasobów ekonomicznych, przepływu: kapitału, siły roboczej oraz technologii i informacji (Kuciński 1997: 179-180). Aby mówić o regionie ekonomicznym, konieczne jest istnienie wewnątrz regionu powiązań ekonomiczno-społecznych, które zapewniają przepływ czynników wytwórczych. Każdy region ekonomiczny posiada następujące cechy (Fajferek 1966: 9): stanowi część większego terytorium; ma określoną specjalizację produkcyjno-usługową w ramach całego kraju; składa się z podobnych jednostek elementarnych; ma co najmniej jeden ośrodek miejski; stanowi obszar przestrzennie zwarty o mniejszym lub większym stopniu domknięcia. Współcześnie region należy traktować jako obszar współpracy społecznej i gospodarczej. W badaniach nad regionami uwaga została zwrócona na: procesy innowacyjne, mechanizmy uczenia się, transfer wiedzy, współpracę poszczególnych podmiotów w układzie regionalnym i lokalnych. Szczególnie ważna jest bliskość przestrzenna podmiotów, która ułatwia proces akumulacji wiedzy i jej transfer. Powyższe stwierdzenia wskazują, iż region może być definiowany także przez pryzmat istniejących powiązań sieciowych podmiotów zarówno ze sfery publicznej, gospodarczej, jak i naukowej. W tym sensie poja- 
wia się pojęcie „terytorium” rozumianego jako zbiór funkcji i powiązanych ze sobą aktywności mających miejsce w określonym obszarze i między zdefiniowanymi podmiotami $\mathrm{w}$ ramach formalnych i nieformalnych powiązań (Nowakowska 2013). Region jako wydzielony obszar jest uczestnikiem procesów rynkowych oraz jednocześnie jest on pod działaniem tych procesów. W kontekście globalizacji region stał się tyglem rozwoju gospodarczego i tworzenia bogactwa narodowego. Konsekwencją tego jest to, iż region powinien być pierwszoplanowym obszarem skupienia się polityki gospodarczej (Łaźniewska, Gorynia 2012: 20).

Zmiana podejścia do pojmowania regionu jest skutkiem przyśpieszenia rozwoju cywilizacyjnego, przewartościowania czynników produkcji oraz globalnych tendencji rozwojowych, tj.: wzrost znaczenia nauki i edukacji w gospodarce, bezpośrednie przekształcanie wiedzy w zasób produkcyjny, szybki rozwój technologii informacyjnych, pojawienie się nowych zawodów wykorzystujących umiejętności informatyczne (Polska 2025: 23-34). W literaturze podkreśla się znaczenie konkurencyjności regionów. Jest to kategoria nieco odmienna od konkurencyjności przedsiębiorstwa, gdyż region jako konstrukcja trwała nie może zniknąć z powierzchni ziemi, musi istnieć. Badania konkurencyjności regionu poddają analizie czynniki rozwojowe w ujęciu dynamicznym, które określają zdolność do osiągnięcia i utrzymania osiągniętej pozycji konkurencyjnej (Bieńkowski 1995: 35). Czynniki rozwoju regionalnego zmieniają swoją wagę wraz z rozwojem sytuacji gospodarczej, wymogami gospodarki globalnej i postępu technologicznego. Niektóre z tradycyjnie zdefiniowanych czynników, takich jak: dostępność do surowców, bliskość krajowych i międzynarodowych szlaków komunikacyjnych, kwalifikacje siły roboczej uzupełniane są o: kapitał społeczny i ludzki, a także poziom rozwoju i jakość powiązań sieciowych. Ostatnie wydarzenia wskazują także, iż stabilizacja polityczna, a także siła związków zawodowych jako czynniki rozwoju regionalnego nabierają większego znaczenia.

\section{KLASTRY W WOJEWÓDZTWIE ŚWIĘTOKRZYSKIM}

Koncepcja klastrów jakkolwiek jest wynikiem opisów procesów grupowania się przedsiębiorstw, tłumaczonych w koncepcjach korzyści aglomeracji, a ściślej mówiąc, korzyści lokalizacji, ma swoje umocowania w rozważaniach na temat rozwoju regionalnego. Teoria klastrów Portera jest wyraźnie związana z przewagą konkurencyjności regionalnej rozumianej jako przewaga konkurencyjności firm, branż oraz gospodarek narodowych (Łaźniewska, Gorynia 2012: 21).

Województwo świętokrzyskie to region: zajmujący 3,7\% powierzchni kraju, mający $2,4 \%$ udziału w wytworzeniu PKB (w cenach bieżących) Polski, zaliczany do najsłabiej rozwiniętych regionów Polski, gdyż PKB per capita w województwie stanowił $73,8 \%$ średniej krajowej. Cechą wyróżniającą województwo jest 
wysoki udział osób zatrudnionych w rolnictwie - 24\% ogółu zatrudnionych (średnia dla Polski $12,6 \%)^{1}$. W raporcie atrakcyjności inwestycyjnej świętokrzyskie zajmowało 15. miejsce wśród wszystkich województw (Nowicki 2012). Niska ocena atrakcyjności inwestycyjnej województwa świętokrzyskiego wynika głównie z: słabej dostępności transportowej, braku odpowiedniej infrastruktury gospodarczej (wzięto tutaj pod uwagę gęstość instytucji otoczenia biznesu, obecność ośrodków naukowo-badawczych, liczbę imprez targowo-wystawienniczych, funkcjonowanie specjalnych stref ekonomicznych), niskiej chłonności regionalnego rynku oraz słabej infrastruktury społecznej (Nowicki 2012).

Według danych zgromadzonych w PARP w województwie świętokrzyskim funkcjonuje łącznie 15 klastrów i inicjatyw klastrowych. Ze względu na poziom sformalizowania i funkcjonowania można wskazać na następujące klastry w województwie świętokrzyskim:

- Klaster usługowy Grono Targowe Kielce,

- Świętokrzysko-Podkarpacki Klaster Budowlany,

- Świętokrzysko-Podkarpacki Klaster Energetyczny,

- Wschodni Klaster Odlewniczy KOM-CAST,

- Klaster Zdrowie i Turystyka „Uzdrowiska Perły Polski Wschodniej”.

Klaster Grono Targowe Kielce działa jako izba gospodarcza od 2006 r. Tworzą go podmioty głównie z sektora usługowego, stanowiące zaplecze dla organizacji wydarzeń targowo-konferencyjnych. Świętokrzysko-Podkarpacki Klaster Budowlany formalnie funkcjonuje od 2009 r., kiedy to została podpisana umowa o współpracy pomiędzy jego członkami. Świętokrzysko-Podkarpacki Klaster Energetyczny - nieformalnie funkcjonował od 2003 r. jako klaster producentów biomasy, tworzyło go wtedy 27 podmiotów, które umownie nazwało inicjatywę „Konsorcjum Biomasa Świętokrzyska”. Pod nazwą klaster energetyczny funkcjonuje on od 2009 r. Wschodni Klaster Odlewniczy KOM-CAST działa w formie stowarzyszenia od 2006 r., jego członkami są przedsiębiorstwa z woj. świętokrzyskiego, podkarpackiego i lubelskiego. Kolejny klaster usługowy to Klaster Zdrowie i Turystyka „Uzdrowiska Perły Polski Wschodniej” działający w formie stowarzyszenia od czerwca 2009 r., skupiający podmioty z województw: lubelskiego, podkarpackiego, świętokrzyskiego działające w branży turystyki zdrowotnej i uzdrowiskowej.

W wymienionych klastrach na terenie województwa świętokrzyskiego działają 103 przedsiębiorstwa z sektora małych i średnich, co stanowi 0,09\% tych podmiotów zarejestrowanych $\mathrm{w}$ REGON w województwie świętokrzyskim w 2013 r. Znaczenie klastrów dla rozwoju regionu zostało podkreślone w dokumentach strategicznych, tj. Regionalnej Strategii Innowacji oraz Strategii Roz-

${ }^{1}$ Wysoki odsetek osób zatrudnionych w rolnictwie mają województwa: lubelskie $(27,7 \%)$, podlaskie $(25,1 \%)$. 
woju Województwa Świętokrzyskiego do 2020 r. W obu dokumentach przypisuje się klastrom pozytywny wpływ na rozwój regionu i podkreśla ich znaczenie dla jego konkurencyjności i możliwości absorpcji innowacji (Kraska 2013: 39-47), jednak nie zostały w tym zakresie przeprowadzone badania, które by weryfikowały to stwierdzenie.

\section{OTOCZENIE NAUKOWE W WOJEWÓDZTWIE ŚWIĘTOKRZYSKIM}

W obszarze nauki w Polsce możemy wyróżnić: Polską Akademię Nauk i jej oddziały - zajmuje się ona badaniami podstawowymi; jednostki badawczorozwojowe, które działają głównie w obszarze badań wdrożeniowych i prac rozwojowych; szkoły wyższe - podstawowym ich zadaniem jest działalność edukacyjna, uzupełnieniem ich jest prowadzenie działalności badawczej. W Polsce w 2012 r. działało 19 uniwersytetów oraz 453 szkoły wyższe. W województwie świętokrzyskim działają:

- dwie publiczne uczelnie akademickie, tj. Uniwersytet Jana Kochanowskiego oraz Politechnika Świętokrzyska, mające siedzibę w Kielcach,

- jedna Państwowa Wyższa Szkoła Zawodowa w Sandomierzu,

- dwanaście niepublicznych uczelni.

Poza wymienionymi wyżej uczelniami, na terenie województwa świętokrzyskiego funkcjonują dwie uczelnie spoza regionu, tj. Wyższa Szkoła Finansów i Informatyki im. prof. Janusza Chechlińskiego w Łodzi - wydział zamiejscowy w Starachowicach oraz Uniwersytet Ekonomiczny w Krakowie - Zamiejscowy Ośrodek Dydaktyczny w Kielcach. W wymienionych uczelniach i szkołach wyższych zatrudnionych jest 1696 nauczycieli akademickich, w tym na stanowisku: profesora $27,36 \%$, docenta $2,60 \%$, adiunkta 37,80\%. W 2012 r. liczba jednostek, które prowadziły działalność badawczo-rozwojową w województwie świętokrzyskim ogółem była równa 50 (stanowiło to 1,83\% tych jednostek w Polsce), $\mathrm{z}$ czego 42 działało $\mathrm{w}$ sektorze przedsiębiorstw. Zatrudnienie $\mathrm{w}$ tym samym okresie $\mathrm{w}$ działalności $\mathrm{B}+\mathrm{R}$ na tysiąc aktywnych zawodowo kształtowało się na poziomie 0,8 przy średniej krajowej 5,2 . W województwie świętokrzyskim nie ma placówek naukowych Polskiej Akademii Nauk. Nakłady na działalność B+R od 2002 r. z poziomu $0,07 \%$ PKB uległy zwiększeniu do poziomu 0,3\% PKB w 2012 r., jednak nadal kształtują się one poniżej średniej krajowej $(0,9 \%$ PKB). Pod względem poziomu innowacyjności województwo znacznie odbiega od średniej krajowej (Tabela 1), nakłady na działalność innowacyjną w przemyśle w 2012 r. stanowiły 63,9\% nakładów w przemyśle w Polsce. Głównymi źródłami finansowania działalności innowacyjnej świętokrzyskich przedsiębiorstw przemysłowych były środki własne, które stanowiły 85,8\% wszystkich nakładów. Efektywność poniesionych nakładów na działalność innowacyjną znajduje odzwierciedlenie w liczbie zgłoszonych wynalazków, uzyskanych 
patentów czy wzorów użytkowych. W 2012 r. z województwa świętokrzyskiego do urzędu patentowego zgłoszonych zostało 70 wynalazków krajowych i 21 wzorów użytkowych, zaś prawo patentu zostało przydzielone 39 wynalazkom oraz 17 wzorom użytkowym.

Tabela 1. Innowacyjność gospodarki województwa świętokrzyskiego na tle Polski w 2012 roku

\begin{tabular}{|l|c|c|}
\hline \multicolumn{1}{|c|}{ Wyszczególnienie } & Świętokrzyskie & Polska \\
\hline Nakłady na działalnośc innowacyjną w przemyśle w mln zł & 806,7 & 21535,4 \\
\hline $\begin{array}{l}\text { Udział przedsiębiorstw przemysłowych, które prowadzą } \\
\text { działalność innowacyjną (\%) }\end{array}$ & 13,12 & 12,90 \\
\hline Źródła finansowania nakładów na działalność innowacyjną & & \\
w przemyśle (\%): & & \\
- własne & 85,8 & 82,4 \\
- środki budżetowe & 0,0 & 2,2 \\
- pozyskane z zagranicy (bezzwrotne) & 13,8 & 8,0 \\
- kredyty bankowe & 0,4 & 7,4 \\
\hline Nakłady na działalność innowacyjną w sektorze usług & 72,5 & 15145,4 \\
(w mln zł) & & \\
\hline Liczba zgłoszonych wynalazków krajowych, w tym \% & 70 & 4410 \\
udzielonych patentów & 55,7 & 41,9 \\
\hline Liczba zgłoszonych wzorów użytkowych krajowych & 21 & 941 \\
\hline Liczba udzielonych praw ochronnych & 17 & 514 \\
\hline
\end{tabular}

Źródło: opracowanie własne na podstawie Banku Danych Lokalnych http://stat.gov.pl (dostęp 18.07.2014).

\section{WYNIKI BADAŃ}

Podmioty gospodarcze nawiązują współpracę z otoczeniem tylko wtedy, gdy zapewni im ono analogicznie osiągnięcie ich celów, do których najczęściej należą (Stępień 2011: 71): obniżenie kosztów funkcjonowania, skrócenie czasu realizacji określonych zadań, zwiększenie jakości oferowanych dóbr i usług, ograniczenie ryzyka wykonywania działalności gospodarczej, wzrost konkurencyjności i innowacyjności. Wyniki badań obejmują opis współpracy między przedsiębiorstwami zlokalizowanymi w klastrach, a partnerami zewnętrznymi. Na ich tle zostanie przestawiona analiza współpracy jednostek gospodarczych z otoczeniem naukowym.

W 2014 r. wśród sformalizowanych klastrów zlokalizowanych w woj. świętokrzyskim przeprowadzono badania metodą PAPI (wywiad bezpośredni realizowany przy użyciu papierowego kwestionariusza badawczego wypełnianego przez ankietera). Przebadanych zostało 50 przedsiębiorstw działających w klastrach. Wszystkie zbadane przedsiębiorstwa od momentu powstania prowadzą działalność w województwie świętokrzyskim, z czego tylko $6 \%$ powstało jako filia przedsiębiorstwa zlokalizowanego poza województwem świętokrzyskim. 
Badane przedsiębiorstwa są ściśle związane z regionem świętokrzyskim, gdyż głównym miejscem prowadzenia przez nich działalności gospodarczej jest regionalny rynek. Ponadto $86 \%$ badanych lokuje swoją sprzedaż głównie w województwie, w tym:

- $18 \%$ badanych lokuje $100 \%$ swojej sprzedaży w regionie świętokrzyskim,

- $16 \%$ badanych od $80 \%$ do $90 \%$ sprzedaży,

- $24 \%$ badanych od $50 \%$ do $80 \%$,

- $28 \%$ badanych poniżej $50 \%$.

Wyniki badań pokazują, że członkowie świętokrzyskich klastrów współpracują z (Wykres 1): odbiorcami (96\% badanych), dostawcami (92\%), przedsiębiorstwami o podobnym profilu działalności gospodarczej $(88 \%)$, jednostkami samorządu terytorialnego (70\%), organizacjami branżowymi $(68 \%)$, instytucjami finansowymi (68\%), instytucjami finansowo-ubezpieczeniowymi (66\%), z uczelniami zlokalizowanymi w regionie (64\%), instytucjami otoczenia biznesu (56\%), jednostkami badawczo-rozwojowymi (56\%), indywidualnymi naukowcami (42\%), uczelniami spoza regionu świętokrzyskiego (32\%).

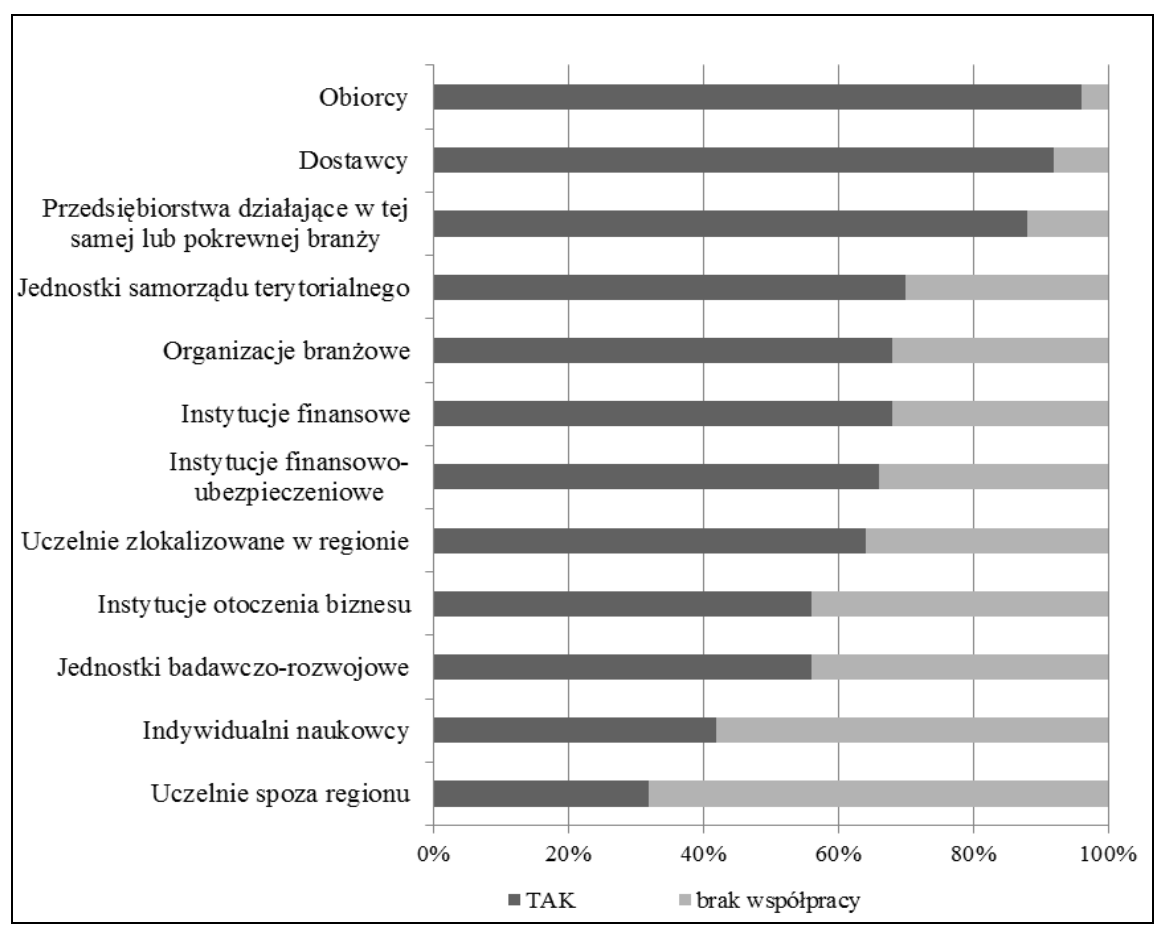

Wykres 1. Partnerzy współpracy

Źródło: opracowanie własne na podstawie wyników badań. 
W regionie świętokrzyskim działa 15 uczelni wyższych, w tym jedna techniczna, jeden uniwersytet, dwie wyższe szkoły ekonomiczne, dziewięć państwowych wyższych szkół zawodowych oraz jedna szkoła teologiczna. Najszerszą ofertę w regionie dla przemysłu w zakresie nowych technologii i wyspecjalizowanych laboratoriów oferuje Politechnika Świętokrzyska, która jest członkiem Świętokrzysko-Podkarpackiego Klastra Energetycznego oraz Świętokrzysko-Podkarpackiego Klastra Budowlanego. Współpracę z uczelniami w regionie podejmuje $64 \%$ badanych, w tym w $55 \%$ jest to współpraca formalna oparta o stosowane umowy. Najczęściej przedsiębiorstwa współpracują z uczelniami przy pozyskiwaniu pracowników (44,0\%), organizacji szkoleń, konferencji i seminariów $(34,4 \%)$ oraz prowadzeniu wspólnych prac badawczo-rozwojowych $(34,4 \%)$ (Wykres 2). W mniejszym zakresie dotyczy ona dystrybucji dóbr i usług $(25,0 \%)$, prowadzenia wspólnych działań marketingowych, promocyjnych $(21,9 \%)$, realizacji wspólnych projektów unijnych oraz krajowych $(21,8 \%)$, wytwarzania dóbr i usług $(21,9 \%)$, wspólnego aplikowania o środki zewnętrzne $(12,5 \%)$.

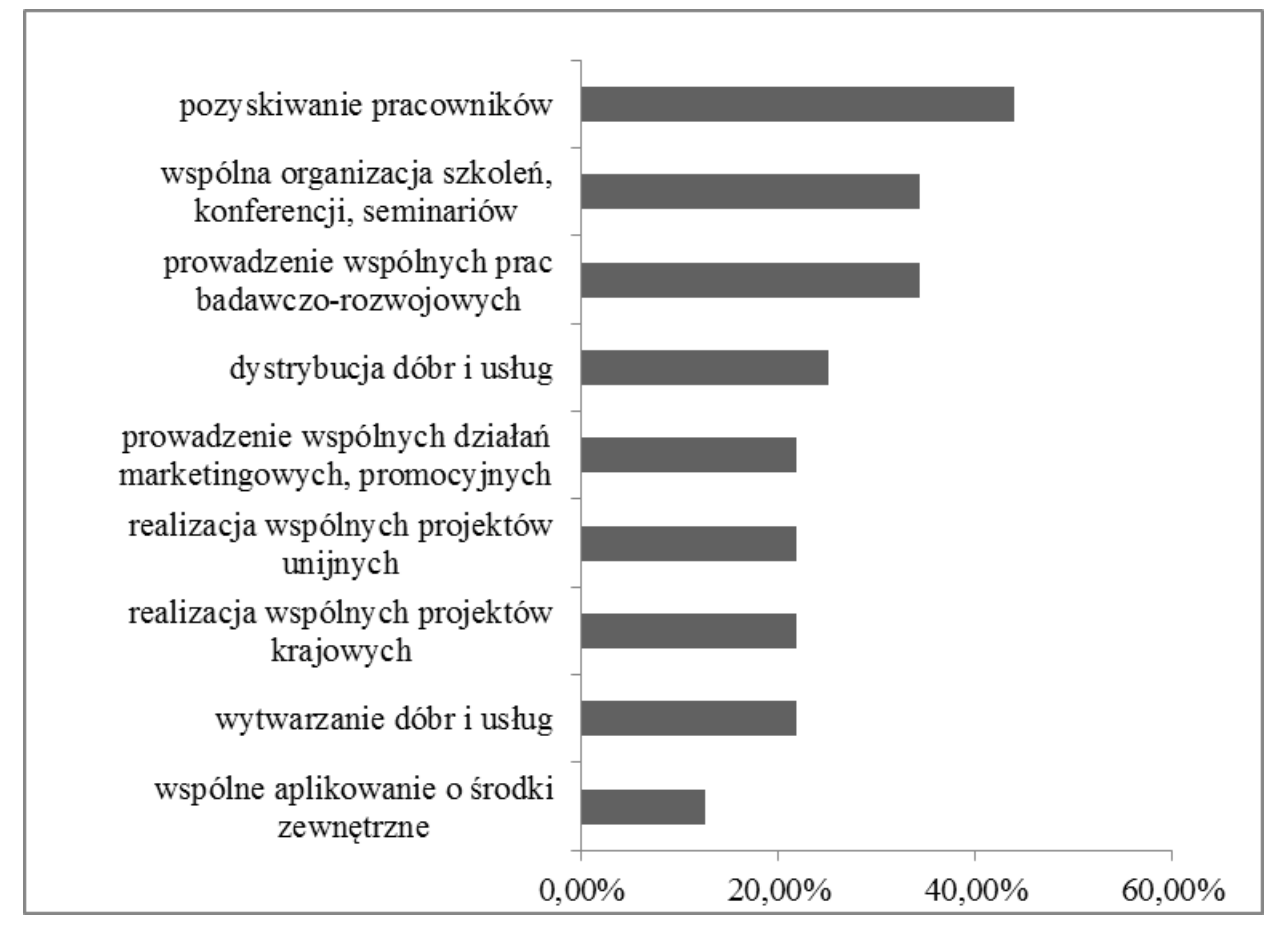

Wykres 2. Obszary współpracy pomiędzy przedsiębiorstwami w klastrach a uczelniami wyższymi w regionie

Źródło: opracowanie własne na podstawie wyników badań. 
Z uczelniami spoza regionu świętokrzyskiego współpracę zadeklarowało $32 \%$ badanych przedsiębiorstw. Współpraca ta głównie opiera się na nieformalnych ustaleniach (75\% badanych), co może być wynikiem zbyt skomplikowanych przepisów prawnych dotyczących współpracy publiczno-prywatnej. Większość przedsiębiorstw współpracę z uczelniami spoza regionu podejmuje przy organizacji szkoleń, konferencji i seminariów $(37,5 \%)$ oraz prowadzeniu wspólnych prac badawczo-rozwojowych $(37,5 \%)$. Co piąte przedsiębiorstwo wspó1pracuje w zakresie aplikowania o środki zewnętrzne, wytwarzania dóbr i usług oraz realizacji projektów unijnych. W najmniejszym zakresie przedsiębiorstwa podejmują współpracę polegającą na realizacji wspólnych projektów krajowych oraz prowadzeniu wspólnych działań marketingowych oraz promocyjnych (Wykres 3). Należy zauważyć, iż współczesne przedsiębiorstwo nie jest w stanie funkcjonować bez nawiązywania relacji $\mathrm{z}$ otoczeniem. Współpraca pomiędzy przedsiębiorstwami a uczelniami powinna być długofalowa ze względu na efekty przez nią generowane nie tylko w krótkim i średnim horyzoncie czasu. Uczelnie w regionie posiadają odpowiednie zaplecze infrastrukturalne, które powinno być efektywnie wykorzystane nie tylko na potrzeby pracowników naukowych, lecz również przez przedsiębiorstw, które $\mathrm{z}$ kolei nie mają $\mathrm{w}$ swej strukturze jednostek $\mathrm{B}+\mathrm{R}$.

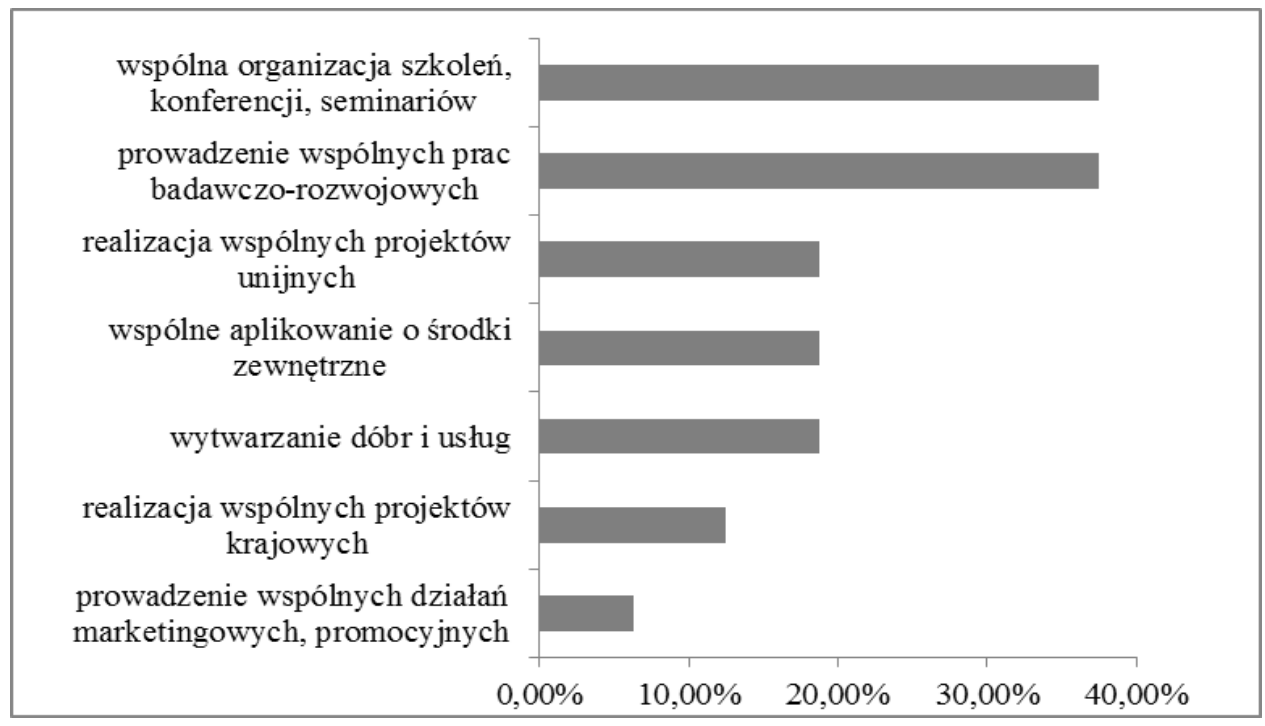

Wykres 3. Obszary współpracy pomiędzy przedsiębiorstwami w klastrach a uczelniami wyższymi spoza regionu

Źródło: opracowanie własne na podstawie wyników badań. 
Analizując poziom współpracy przedsiębiorstw zlokalizowanych w klastrach $\mathrm{w} \mathrm{z}$ otoczeniem naukowych, zbadano również ich powiązania z podmiotami z sektora badawczo-rozwojowego. Współpracę z jednostkami badawczo-rozwojowymi zadeklarowała ponad połowa badanych (56\%). Najczęściej współpraca dotyczyła wytwarzania dóbr i usług $(25,0 \%)$, prowadzenia wspólnych prac badawczo-rozwojowych $(25,0 \%)$, wspólnego aplikowania o środki zewnętrzne (14\%). Według danych zgromadzonych w GUS w zakresie działalności innowacyjnej współpracę podjęło 6,3\% ogółu przedsiębiorstw przemysłowych w województwie świętokrzyskim, jednak nie ma dokładnej informacji o podmiotach będących stornami w tej współpracy. Według raportu opracowanego przez PARP w okresie od 2006 do 2008 r. 39\% zbadanych przedsiębiorstw współpracowało z co najmniej jednym podmiotem, zaś tylko $12 \%$ przedsiębiorstw współpracowało $\mathrm{z}$ uniwersytetami lub innymi instytucjami edukacji wyższej (Innowacyjność 2010: 54). Współpraca przedsiębiorstw ze środowiskiem naukowym nie tylko w województwie świętokrzyskim, lecz również w całej Polsce jest trudna, gdyż: „Uczelnia koncentrując się na swej misji edukacyjnej oraz naukowej, nie jest podmiotem rynkowym działającym w zgodności z jego rygorami, zgodnie z praktyką kodeksu spółek handlowych i przepisów prawa gospodarczego. Wchodzenie we wspólne przedsięwzięcia biznesowe $\mathrm{z}$ uniwersytetami niesie za sobą nieprzewidywalne zdarzenia i znacznie podwyższa ryzyko finansowe" (Kaczmarek, Woźnicki 2006: 10). Ponadto każdy z podmiotów oczekuje innych rezultatów współpracy. Dotychczasowe badania pokazują, że najczęściej współpraca pomiędzy sektorem nauki i przedsiębiorstw dotyczyła: prowadzenia wspólnych prac badawczo-rozwojowych, wykorzystania laboratoriów uczelni do przeprowadzenia określonych badań, podnoszenia kwalifikacji pracowników dzięki uczestnictwu w kursach, studiach podyplomowych organizowanych przez uczelnie, udziału w konferencjach i seminariach naukowych, organizacji targów pracy, dzięki którym przedsiębiorstwa pozyskują praktykantów i pracowników, realizacji wspólnych projektów krajowych i unijnych, współpracy w zakresie wdrożeń nowego produktu lub usługi na rynek, członkowstwa przedsiębiorstwa $\mathrm{w}$ organach uczelni jako ciała doradczego (Arendt 2011: 18). Skłonność przedsiębiorstw do współpracy jest uwarunkowana wieloma czynnikami, jednym z najważniejszych jest poziom zaufania społecznego. Według badań CBOS-u z 2014 r. (Zaufanie społeczne 2014) Polacy ufają przede wszystkim osobom, które znają, tj.: rodzinie ( $97 \%$ respondentów), znajomym (91\%), dalszym krewnym (87\%), współpracownikom (82\%). Osobom nieznajomym nie ufa 55\% respondentów. Zaufanie w kontaktach biznesowych ma tylko 33\% ankietowanych, co nie sprzyja nawiązywaniu wszelkiego rodzaju współpracy zarówno pomiędzy przedsiębiorstwami, jak i instytucjami otoczenia naukowego. 


\section{PODSUMOWANIE}

Istotność powiązań sieciowych nauka-biznes dla rozwoju regionalnego i klastrów jest niepodważalna. Nawiązując do koncepcji Gospodarki Opartej na Wiedzy (GOW) jest ona jednym z determinantów procesów rozwoju regionalnego jako efektu budowania silnej, stabilnej i konkurencyjnej gospodarki regionalnej, a w efekcie narodowej. Badania przedsiębiorstw zlokalizowanych w klastrach województwa świętokrzyskiego wskazują, iż doceniają one ten obszar współpracy. Zakres współpracy z instytucjami otoczenia naukowego zlokalizowanymi w województwie zależy zaś głównie od potencjału regionu w tym zakresie. Badania wykazały, iż przedsiębiorstwa zlokalizowane w klastrach województwa świętokrzyskiego poszukują partnerów ze środowiska naukowego tak w regionie, jak i poza nim, przy czym wyraźnie widoczna jest przewaga liczby przedsiębiorstw współpracujących $\mathrm{z}$ uczelniami $\mathrm{w}$ regionie świętokrzyskim (64\%) niż poza nim (32\%). Zakres współpracy odnoszący się do wspólnie podejmowanych inicjatyw jest zbliżony, co oznacza, iż zarówno partnerzy regionalni, jak i pozaregionalni oferują te same ścieżki współpracy. Przewaga przedsiębiorstw współpracujących $\mathrm{z}$ partnerami regionalnymi uwarunkowana jest względami nie tylko bliskości terytorialnej, ale także zakorzenieniem w lokalnej tradycji i związkami z regionalnymi instytucjami otoczenia rynkowego. Ponadto duże znaczenie mają inicjatywy podejmowane przez regionalne uczelnie mające na celu zacieśnianie współpracy z najbardziej innowacyjnymi i prężnie działającymi firmami w regionie. Współdziałanie przedsiębiorstw zlokalizowanych w klastrach województwa świętokrzyskiego z partnerami naukowymi spoza regionu jest zrozumiałe ze względu na jego ograniczony potencjał naukowy. Przewrotnie można powiedzieć, iż taka sytuacja jest korzystna, ponieważ prowadzi do transferu wiedzy do przedsiębiorstw województwa świętokrzyskiego, a nie jest związana $\mathrm{z}$ eksportem kapitału i miejsc pracy. Instytucje otoczenia biznesu w regionie, tj. Staropolska Izba Przemysłowo-Handlowa, Świętokrzyskie Centrum Innowacji i Transferu Technologii, Kielecki Park Technologiczny wpierają współpracę pomiędzy sektorem nauki i biznesu poprzez realizowane projekty, których głównym celem są działania promujące transfer wiedzy i innowacji oraz kojarzenie partnerów w zakresie działalności $\mathrm{B}+\mathrm{R}$. Współpraca między sferą gospodarki a sferą nauki będzie się rozwijała, gdyż jest to wymogiem współczesnej ekonomii, który jest uświadamiany przez obu partnerów. Pozytywnym wnioskiem $\mathrm{z}$ badań jest to, iż ta współpraca jest doceniana przez jednostki gospodarcze zlokalizowane w klastrach uznawanych za nośniki rozwoju gospodarczego i regionalnego. Trzeba mieć jednak świadomość, iż skala oraz formy tej współpracy wynikają nie tylko ze stopnia rozwoju świadomości przedsiębiorców, ale także rozwoju gospodarczego wyznaczającego zdolność absorpcji efektów badań naukowych przez przedsiębiorstwa zlokalizowane w regionie. 


\title{
BIBLIOGRAFIA
}

Arendt Ł. (2011), Raport z badań w projekcie Uczelnia Przyjazna Pracodawcom, Warszawa.

Bieńkowski W. (1995), Reganomika i jej wpływ na konkurencyjność gospodarki amerykańskiej, Warszawa.

Zaufanie spoteczne $w$ 2014, http://www.cbos.pl/SPISKOM.POL/2014/K_029_14.PDF [Dostęp 18.07.2014].

Fajferek A. (1966), Region ekonomiczny i metody analizy regionalnej, Warszawa.

Bank Danych Lokalnych, http://stat.gov.pl [Dostęp 18.07.2014].

Kaczmarek A, Woźnicki J. (2006), Regulacje prawne, dobre wzorce i praktyki dotyczace korzystania przez podmioty gospodarcze z wyników prac badawczych i innych osiagnięć intelektualnych instytucji akademickich i naukowych, Warszawa.

Kraska E. (2013), Klastry w polityce regionalnej województwa świętokrzyskiego, „Studia i Materiały. Miscellanea Oeconomicae" nr 1, s. 39-47.

Kuciński K. (1997), Geografia ekonomiczna. Zarys teoretyczny, Warszawa.

Łaźniewska E., Gorynia M. (red.) (2012), Konkurencyjność regionalna. Koncepcje - strategie przyktady, Warszawa.

Nowakowska A. (red.) (2013), Zrozumieć terytorium. Idea i praktyka, Łódź.

Nowicki M. (red.) (2012), Atrakcyjność inwestycyjna województw i podregionów Polski, Gdańsk.

Innowacyjność 2010, Warszawa; http://www.parp.gov.pl/files/74/81/380/10838 [Dostęp 18.07.2014].

Polska 2025. Dlugookresowa strategia trwałego i zrównoważonego rozwoju, (2000), Rada Ministrów, Rządowe Centrum Studiów Strategicznych, Warszawa.

Stępień B. (red.) (2011), Międzynarodowa kooperacja gospodarcza z polskiej perspektywy, Warszawa.

Stawasz D. (2000), Wspótczesne uwarunkowania rozwoju polskich regionów, Łódź.

Janusz Kot, Ewa Kraska

\section{COOPERATION OF COMPANIES WITHIN CLUSTERS OF THE SCIENTIFIC COMMUNITY RELATED TO REGIONAL DEVELOPMENT PROCESSES (FOR EXAMPLE, IN THE ŚWIĘTOKRZYSKIE REGION)}

\begin{abstract}
This article contains an analysis of the relationships between companies belonging to clusters in the Świętokrzyskie scientific community. These relationships are the subject of research, both in terms of geographic reach (regional and beyond), and in terms of forms of cooperation. The findings presented in this paper form the basis for conclusions about the significance of cooperation between both the economic and scientific spheres, in: shaping clusters, the development of companies within them, as well as regional development as a whole.
\end{abstract}

Keywords: business cluster; research environment; regional development. 